\title{
Amphibia, Anura, Centrolenidae Teratohyla midas (Lynch and Duellman, 1973) and Cochranella resplendens (Lynch and Duellman, 1973): First and second record respectively for Colombia
}

\author{
César Malambo ${ }^{1,2 *}$, Junner F. González-Ibarra ${ }^{2}$ and Yudi C. Gomez-Polania ${ }^{2,3}$ \\ 1 Corporacion Educativa Amigos Instituto Jean Piaget, Km 3 vía al Aeropuerto Florencia, Caquetá. \\ 2 Universidad de la Amazonia, Grupo de Investigación en Biodiversidad y Desarrollo Amazónico BYDA y Semillero de Investigación en Anfibios y \\ Reptiles CROACK, Florencia-Caquetá, Colombia. \\ 3 Empresa de servicios de Florencia SERVAF S.A. E.S.P., Laboratorio de calidad de agua. Kilómetro 2 planta de tratamiento de agua el Diviso, \\ Florencia-Caquetá, Colombia. \\ * Corresponding author. E-mail: malambidae@gmail.com
}

\begin{abstract}
We present the first record of the glassfrog Teratohyla midas (Lynch and Duellman, 1973) for Colombia. This species, previously known in Ecuador, Peru and French Guiana, was collected at the municipalities of Belén de los Andaquíes and Florencia, Caquetá, Colombia. We also present the second record of Cochranella resplendens (Lynch and Duellman, 1973) for Colombia. The species was previously known from Santa Maria de Sucumbíos, department of Putumayo, Colombia.
\end{abstract}

Glassfrogs of the family Centrolenidae are, a monophyletic group with roughly 150 recognized species (AmphibiaWeb, 2013), arranged in 12 monophyletic genera (Cisneros-Heredia and McDiarmid, 2007; Guayasamin et al. 2008, 2009) that are distributed throughout the Neotropical wet forests from southern Mexico to southern Bolivia. Recent taxonomic efforts on this group of anurans during the last years has led to an increase of its alphadiversity (Kok and Castroviejo-Fisher, 2008; CastroviejoFisher et al. 2009); however, gaps in our basic knowledge of their geographical distribution, mainly in the Andean region of Colombia, still remain (Rivera-Correa, 2010).

Based on data obtained during recent field trips, we report the first record of Teratohyla midas for Colombia and the first record of Cochranella resplendens for Caquetá, a poorly known department of Colombia in terms of its herpetofaunal diversity (Malambo-L and Marin, 2006; Malambo-L and Madrid-Ordoñez, 2008). Specimens herein reported are deposited at the collection of Amphibians of Museo de Historia Natural de la Universidad de la Amazonia, Florencia-Caquetá (UAM). The taxonomic nomenclature follows Guayasamin et al. (2009).

\section{Cochranella resplendens}

Lynch and Duellman (1973) described this species based on one adult individual and a juvenile collected at Santa Cecilia, Napo Province, Ecuador, and Santa Maria de Sucumbíos, Putumayo department, Colombia. CisnerosHeredia and McDiarmid (2005) reported the second and third known localities of the species in Ecuador at the provinces of Pastaza and Orellana. Later, TorresGastello et al. (2007) reported the species from the Alto Cainarachi Valley, department of San Martin, providing the first record for Peru. Finally Terán-Valdez et al. (2009) described the tadpole and reported the new locality
Napinaza river, Morona Santiago province, Ecuador. Cochranella resplendens is considered Least Concern in view of its wide distribution and occurrence in an area of extensive, suitable habitat by the IUCN (Cisneros-Heredia, 2008). A specimen of $C$. resplendens (UAM 1466) was collected at the Microcuenca La Resaca, municipality of Belén de Los Andaquíes, department Caquetá (1²6'23.5" N, 7553'24.5" W, 482 m) on August 072012 by Junner Gonzalez and Arleth Gonzalez (Figure 1).

This frog was captured during the night, perching on the leaves around $0.5 \mathrm{~m}$ above the water of a fast-flowing stream in a secondary forest. The individual is an adult male with $26.38 \mathrm{~mm}$ SVL (snout-vent length) exhibiting all the diagnostic characteristics described by Lynch and Duellman (1973), including: prevomerine teeth, green bones in life, white parietal and visceral peritoneum, color in life dark green with white to bluish green flecks, round snout in dorsal view and gradually inclined anteroventrally

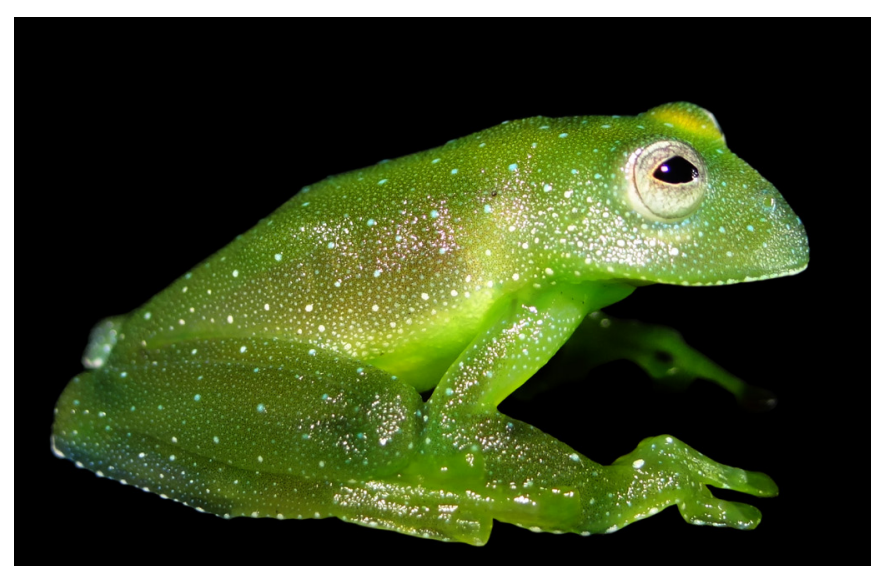

FiguRE 1. Lateral view of Cochranella resplendens, adult male (26.38 mm SVL) from Microcuenca La Resaca, municipality of Belen de Los Andaquíes, department Caquetá, Colombia. Photo by J. Gonzalez. 
in lateral view, scalloped dermal fold on outer edge of hand, forearm, elbow, heel, tarsus, and foot, and U-shaped anal fold. The locality herein reported is the second record for Colombia and is the northernmost report for the species, extending its range ca. $186 \mathrm{~km}$ north airline from its nearest locality in the department of Putumayo (Figure 2).

\section{Teratohyla midas}

Lynch and Duellman (1973) described this species for three localities along the Rio Aguarico in the upper Amazon Basin in Ecuador at elevations between 330-570 m. Rodriguez et al., (2004) reported this species from Panguana, Huánuco department, and Pakitza, Madre de Dios department, in Peru. Lynch (2005) recorded this species as Cochranella sp. for Leticia, Colombia, and Castroviejo-Fisher (pers. conv.) the collected to the same locality in 2009. Cisneros-Heredia and McDiarmid (2005, 2006) reported the species from the Provinces of Orellana, Napo and Pastaza in Ecuador. Kok and Castroviejo-Fisher (2008) first reported Teratohyla midas from French Guiana. Recently it has been registered for the states of Amazonas (França and Venancio 2010) and Rondônia in Brazil (Melo-Sampaio and de Oliveira 2013). Various specimens have been collected in municipalities of Belén de Los Andaquíes and Florencia, Caquetá: Three individuals were collected, in the vereda Sucre, municipality of Florencia (01 ${ }^{\circ} 46^{\prime} 52^{\prime \prime}$ N, 75³9'5.1" W, 950 m) by C. Malambo and W. Trujillo on July 052012 (UAM 1467-69); two individuals were collected at the corregimiento Santo Domingo, farm El Ceilán, municipality of Florencia (1³3’31.64" N, 7540'7.21" W, $295 \mathrm{~m}$ ) by C. Malambo and J. Gonzalez on August 122012 (UAM 1470-71); three specimens were collected at the Microcuenca La Resaca, municipality of Belén de Los Andaquíes (1²6'23.5” N, 7553'24.5” W, 482 m) on August 072012 (UAM 1472-74) by J. Gonzalez and A. Gonzalez (Figure 3).

The adults males of Teratohyla midas ranged from 18.5-20.6 mm SVL and the adult females ranged from 20.8-21.3 $\mathrm{mm}$ SVL exhibiting all the diagnostic characteristics described by Lynch and Duellman (1973), including: prevomerine teeth, bones green in life, parietal peritoneum white, visceral peritoneum clear, dorsum of head body and limbs dark green with a few small yellow flecks dorsolaterally on body, snout truncate in dorsal and lateral profiles, arms and legs lacking dermal folds, humeral spine absent in males and lower two-thirds of tympanum visible, directed dorsolaterally with strong posterior inclination.

The individuals were captured at the night, perching on leaves between $0.7-2.5 \mathrm{~m}$ above the streams. Teratohyla midas and Cochranella resplendens were collected together in the same stream of La Resaca, municipality of Belén de Los Andaquíes. The locality herein reported is the first record for Colombia and is the northernmost report for the species, extending its range ca. $386 \mathrm{~km}$ north airline from its nearest locality in Ecuador

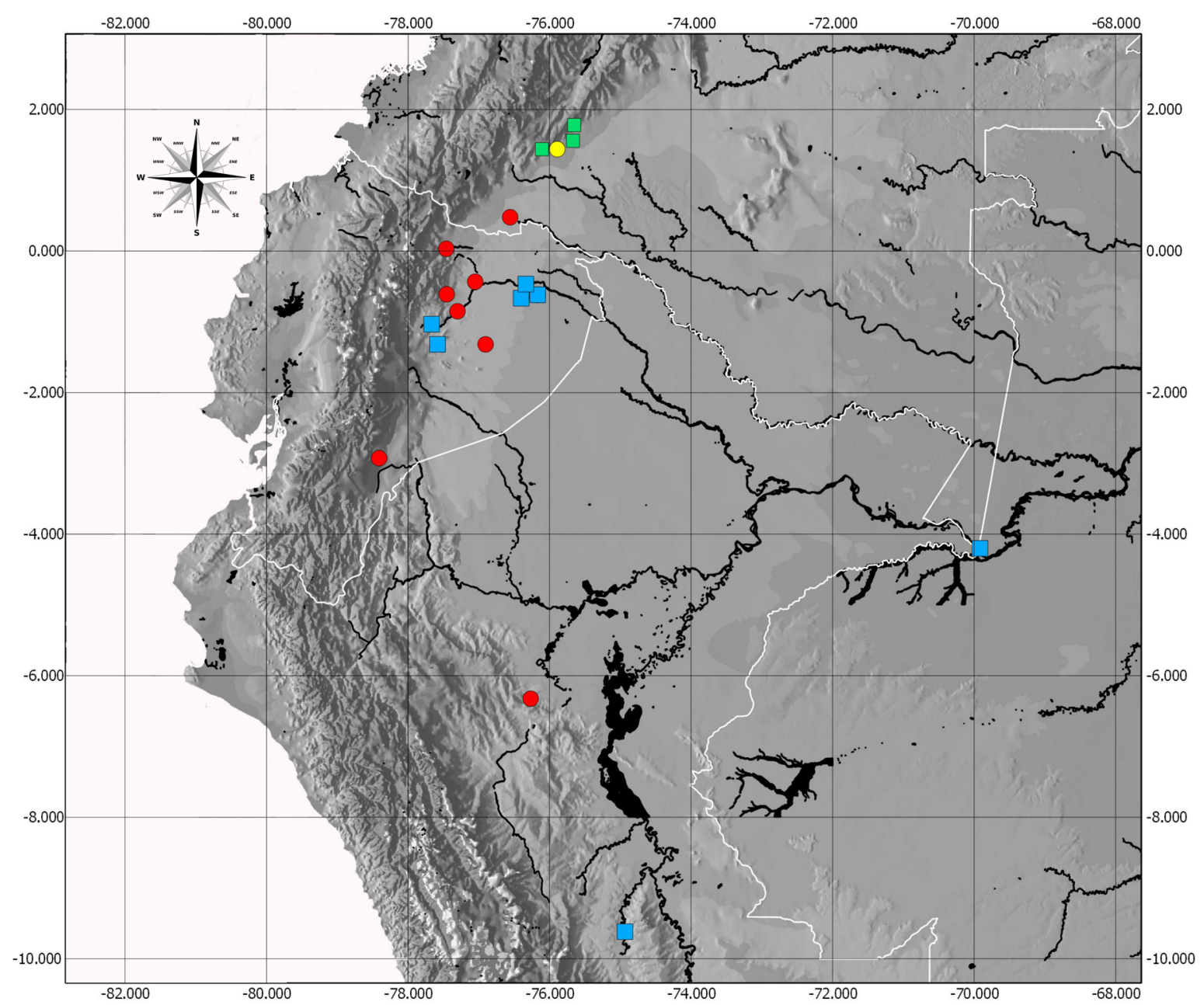

FIGURE 2. Geographical distribution of Cochranella resplendens (yellow circle = new record; red circle = literature record) and Teratohyla midas (green square $=$ new record; blue square $=$ literature record) in western Amazonia. 


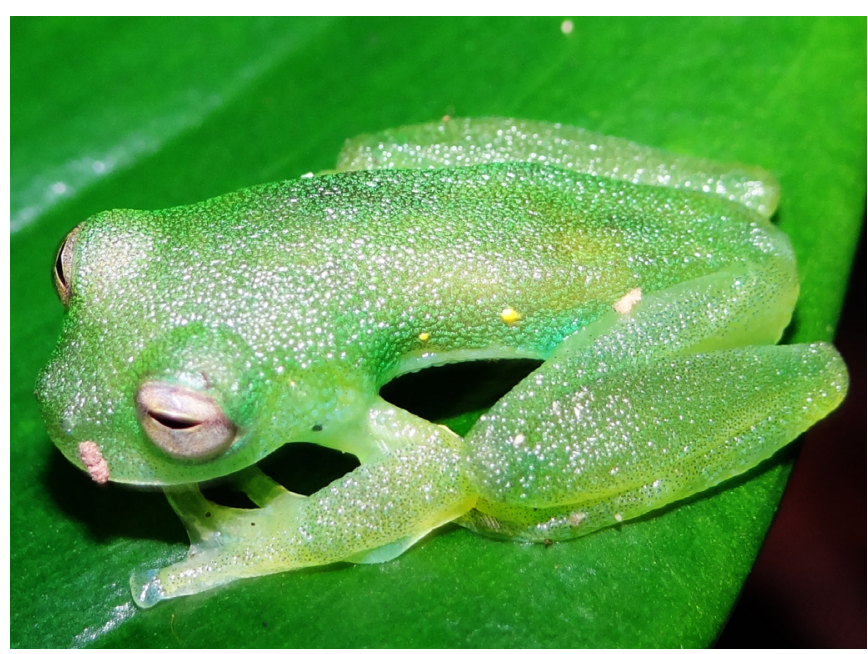

FIGURE 2. Dorsolateral view of Teratohyla midas, adult male $(18.3 \mathrm{~mm}$ SVL) from farm El Ceilan, municipality of Florencia, department Caquetá, Colombia. Photo by J. Gonzalez.

ACKNOWLEDGMents: Special thanks to William Trujillo and Arleth Gonzalez for their field assistance, to David Sánchez, Santiago CastroviejoFisher, Pedro Bernardo, Alexander Arcila and an anonymous referee for valuable comments on the manuscript and revision of English, to Betselene Murcia for permitting us to use her equipment's, to Alexander Claros for the permission to work in the laboratory, and to John D. Lynch and Marco Rada who confirmed the specimen's determination. Partial financial support was provided by programa de becas para la Iniciativa de Especies Amenazadas IEA “Jorge Hernandez Camacho” (convenio CO 522) and by J.J. Sarria and M. Rada.

\section{LITERATURE CiTED}

AmphibiaWeb. 2012. Information on amphibian biology and conservation. Electronic database accessible at http://amphibiaweb.org/. Captured on 26 April 2013.

Castroviejo-Fischer, S., J.M. Padial, J.C. Chaparro, R. Aguayo and I. De la Riva. 2009. A new species of Hyalinobatrachium (Anura: Centrolenidae) from the Amazonian slopes of the central Andes, with comments on the diversity of the genus in the area. Zootaxa 2143: 24-44.

Cisneros-Heredia, D.F. and R.W. McDiarmid. 2005. Amphibia, Centrolenidae, Centrolene peristictum, Centrolene prosoblepon, Cochranella cochranae, Cochranella midas, Cochranella resplendens, Cochranella spinosa, Hyalinobatrachium munozorum: Range extensions and new provincial records. Check List 1(1): 18-22.

Cisneros-Heredia, D.F. and R.W. McDiarmid. 2006. A new species of the genus Centrolene (Amphibia: Anura: Centrolenidae) from Ecuador with comments on the taxonomy and biogeography of Glassfrogs. Zootaxa 1244: 1-32.
Cisneros-Heredia, D.F. and R.W. McDiarmid. 2007. Revision of the characters of Centrolenidae (Amphibia: Anura: Athesphatanura), with comments on its taxonomy and the description of new taxa of glassfrogs. Zootaxa 1572: 1-82.

Cisneros-Heredia D.F. 2008. Cochranella resplendens. In IUCN 2012. IUCN Red List of Threatened Species. Version 2012.1. Electronic database accessible at www.iucnredlist.org. Captured on 10 October 2012.

França, F.G.R. and N.M. Venâncio. 2010. Reptiles and amphibians of a poorly known region in southwest Amazonia. Biotemas 23(3): 71-84.

Guayasamin, J.M., S. Castroviejo-Fisher, J. Ayarzagüena, L. Trueb and C. Vilà. 2008. Phylogenetic relationships of glassfrogs (Centrolenidae) based on mitochondrial and nuclear genes. Molecular Phylogenetics and Evolution 48: 574-595.

Guayasamin, J.M., S. Castroviejo-Fisher, L. Trueb, M. Rada and C. Vilà. 2009. Phylogenetic systematics of Glassfrogs (Amphibia: Centrolenidae) and their sister taxon Allophryne ruthveni. Zootaxa 2100: 1-97.

Kok, P.J.R. and S. Castroviejo-Fisher. 2008. Glassfrogs (Anura: Centrolenidae) of Kaieteur National Park, Guyana, with notes on the distribution and taxonomy of some species of the family in the Guiana Shield. Zootaxa 1680: 25-53.

Lynch, J.D. and W.E. Duellman. 1973. A review of the Centrolenid frogs of Ecuador, with descriptions of new species. Occasional Papers University of Kansas Museum of Natural History, 16: 1-66.

Lynch, J.D. 2005. Discovery of the richest frog fauna in the Worldan exploration of the forests to the north of Leticia. Revista de la Academia Colombiana de Ciencias 29(113): 581-588.

Malambo-L., C. and A. Marin-V. 2006. Geographic distribution: Eleutherodactylus medemi. Herpetological Review 37(4): 487.

Malambo-L. C. and M.A. Madrid-Ordoñez. 2008. Geographic distribution of Limnophys sulcatus, Rhinella castaneotica and Scinax cruentommus (Amphibia: Anura) for Colombia. Revista de la Academia Colombiana de Ciencias 32(123): 285-289.

Melo-Sampaio, P.R. and C.M.B. de Oliveira. 2013. Geographic distribution: Teratohyla midas. Herpetological Review 44(1): 104.

Rivera-Correa, M. 2010. Amphibia, Centrolenidae, Centrolene antioquiense (Noble, 1920): New records and geographical distribution in Colombia. Check List 6(2): 220-221.

Rodríguez, L., J.L. Martinez, C. Azevedo-Ramos, L.A. Coloma and S. Ron 2004. Teratohyla midas. In IUCN 2012. IUCN Red List of Threatened Species. Version 2012.1. Electronic database accessible at www. iucnredlist.org. Captured on 10 October 2012.

Terán-Valdez, A., J.M. Guayasamin and L.A. Coloma. 2009. Description of the tadpole of Cochranella resplendens and redescription of the tadpole of Hyalinobatrachium aureoguttatum (Anura: Centrolenidae). Phyllomedusa 8(2): 105-124.

Torres-Gastello, C.P., J. Suárez-Segovia and D.F. Cisneros-Heredia. 2007. Cochranella erminea, a new species de Centrolenidae (Amphibia: Anura: Athesphatanura) from Amazonian Perú. Journal of the National Museum (Prague), Natural History Series 176(1): 1-12.

RECEIVED: January 2013

ACCEPTED: August 2013

Published Online: September 2013

EDITORIAL RESPONSIBILITY: Pedro Henrique Bernardo 